\section{Tidal Constants at Hyderabad}

THE vertical component of the variations in the gravity field, in milligals, is being continuously recorded in the Department of Geology, Osmania University, at Hyderabad $\left(17^{\circ} 26^{\prime} \mathrm{N} ., 78^{\circ} 27^{\prime} \mathrm{E}.\right)$, as described in an earlier communication ${ }^{1}$. The experimental curve for December 1961 has been analysed by the modified Fourier method ${ }^{2}$ and the 7 main, diurnal and semidiurnal components have been determined. The (Askania gravimeter-GS-11) has been calibrated by the 'tilting' method, as described in the manufacturer's manual, and this enables us to find the actual variation. In this case it is found that $2 \cdot 3 \mathrm{~cm}$ on the ordinate of the record corresponds to 1 mgal.

The theoretical values (mgal) for the 7 components have been obtained from the tide-predicting apparatus located at Dehra Dun. The ratio of the theoretical and the experimentally determined values of the amplitudes of the curve has been calculated and this will enable us to calculate the other characteristic Love numbers $(h, k, l)$, the gravimetric factor $(G)$, diminishing factor $(D)$ and Lambert's constant $(L)$. The results of the present investigation are given in Table 1 . stepfaulted. Where intruded by the dolerite sills shaly members of the formation are metamorphosed to darkgrey or black mica hornfels with cordierite and andalusite. Most of the beds of the formation are horizontal or nearly so.

No fossils have been found in the Roraima Formation, which at different times has been likened to the Torridonian sandstones of Scotland, to Devonian, Permian and Triassic formations of Brazil, to the La Quinta formation which occurs near the Venezuelan and Colombian Andes and to a deposit of Jurassic and Cretaceous age along the Venezuelan Coast Range. On the geological map which accompanies the Handbook of South American Geology ${ }^{1}$ it is shown as 'Triassic continental' while on the latest geological map of the territory prepared by the Geological Survey of British Guiana it is shown as Lower Palæozoic or Precambrian ${ }^{2}$.

Although the sediments of the formation are unsuitable for radiometric age determination, samples of a doleritic sill and its associated mica hornfels from the Kopinang Valley were submitted by the Geological Survey of British Guiana to the Overseas Geological Surveys in the hope that age determinations would set at least a younger limit to the

\begin{tabular}{|c|c|c|c|c|c|c|c|c|c|}
\hline Components & $\begin{array}{c}\text { Experimental } \\
\text { amplitude }\end{array}$ & $\begin{array}{l}\text { Theoretical } \\
\text { amplitude }\end{array}$ & Phase lag & $h$ & $k$ & $l$ & $G$ & $D$ & $L$ \\
\hline $\begin{array}{l}M 2 \\
S 2 \\
N 2 \\
K 2 \\
K 1 \\
O 1 \\
P 1\end{array}$ & $\begin{array}{l}0.083 \\
0.038 \\
0.025 \\
0.017 \\
0.014 \\
0.017 \\
0.049\end{array}$ & $\begin{array}{l}0.069 \\
0.032 \\
0.013 \\
0.007 \\
0.023 \\
0.015 \\
0.009\end{array}$ & $\begin{array}{r}74^{\circ} 52^{\prime} \\
70^{\circ} 6^{\prime} \\
49^{\circ} 27^{\prime} \\
70^{\circ} 20^{\prime} \\
45^{\circ} 18^{\prime} \\
9^{\circ} 58^{\prime} \\
18^{\circ} 45^{\prime}\end{array}$ & $\begin{array}{r}0 \cdot 71 \\
0 \cdot 64 \\
3 \cdot 28 \\
6 \cdot 18 \\
-1.35 \\
0 \cdot 46 \\
15.89\end{array}$ & $\begin{array}{r}0 \cdot 340 \\
0 \cdot 308 \\
1 \cdot 57 \\
2 \cdot 866 \\
-0.651 \\
0 \cdot 223 \\
7.628\end{array}$ & $\begin{array}{c}0 \cdot 092 \\
0 \cdot 083 \\
0 \cdot 43 \\
0 \cdot 803 \\
-0 \cdot 176 \\
0 \cdot 061 \\
2 \cdot 067\end{array}$ & $\begin{array}{l}1 \cdot 2 \\
1.18 \\
1.92 \\
2 \cdot 43 \\
0 \cdot 62 \\
1 \cdot 13 \\
5 \cdot 44\end{array}$ & $\begin{array}{c}0.63 \\
0 \cdot 665 \\
-0 \cdot 071 \\
-2 \cdot 214 \\
1 \cdot 706 \\
0 \cdot 760 \\
7 \cdot 265\end{array}$ & $\begin{array}{l}1 \cdot 248 \\
1 \cdot 224 \\
2 \cdot 144 \\
3 \cdot 163 \\
0 \cdot 525 \\
1 \cdot 162 \\
6 \cdot 561\end{array}$ \\
\hline
\end{tabular}

Although the 7 components have been calculated, $M 2$, which contributes the largest amplitude, can be determined with reasonable accuracy. It is to be regarded as a most significant one and the value obtained for $M 2$ from different stations can be compared. In fact the gravimetric factor $G(1 \cdot 137-1 \cdot 152)$ for the component $M 2$ calculated for the month of December 1961 at Brussels is found to be in fairly good agreement with the similar value obtained at Hyderabad $(1 \cdot 20)$. In the case of $K 1$, the negative values for Love numbers $(h, k, l)$ are probably because the ratio between theoretical and experimental amplitudes $(G)$ is less than unity, and this deserves special attention. Similarly, the negative value in the case of diminishing factor is presumably because of high values of ratios of amplitudes $(G)$. help.

We thank Dr. S. Bhagavantham for his advice and

\section{S. BALAKRISHNA
B. R. LAKSHMI}

Department of Geology, Osmania University, Hyderabad.

'Balakrishna, S., and Johnson, P. V., Curr. Sci., 30, 183 (1961). ${ }^{2}$ Balakrishna, S., and Johnson, P. V., Bull. Nat. Inst. Sci. Ind., No. 22, 13
(1962).

\section{GEOLOGY}

Age of the Roraima Formation, British Guiana

THE Roraima Formation forms part of a series of plateaux and mesas known as the Pakaraima Mountains which extend east-south-east across British Guiana from the boundary with Venezuela and Brazil to the Berbice River. These mountains terminate north-eastwards in a long, irregular series of escarpments which run roughly parallel to and about 140 miles back from the coastline ${ }^{1}$.

The formation consists of stratified sandstones, quartzites, jaspers, shales, conglomerates and boulder beds. It attains its highest known level on the summit of Roraima Mountain $(8,600 \mathrm{ft}$.) while its base in the Ireng River is at $1,400 \mathrm{ft}$. Its true thickness is not clear, as it is intruded by dolerite sills of the Younger Basic Intrusives and is possibly age of this formation. The dolerite sample was collected about $700 \mathrm{ft}$. above the base of a 1,200-ft. thick sill in the Kopinang Valley and the hornfels, which is metamorphosed Roraima shale, from $5 \mathrm{ft}$. above the upper contact of the same sill. The dolerite consists mainly of plagioclase and clino-pyroxene altering to hornblende. Small amounts of biotite are also present. Separation of this biotite proved impossible and the age determination given in Table 1 was made on the pyroxene-hornblende component. The hornfels consists of fine-grained biotite, mica, quartz, and plagioclase. Age determinations were made on both the muscovite and the biotite.

Argon was extracted in a bakeable glass vacuum apparatus and determined by isotope dilution with argon-38 in a Reynolds type glass mass spectrometer. Potassium was determined by direct comparison with standard soltions using an EEL flame photometer. In the case of the pyroxene-hornblende concentrate the dilution-addition method proposed by Grimaldi ${ }^{3}$, was used.

The results of the determinations are in good agreement and give a weighted mean of $1,710 \mathrm{~m} . \mathrm{y}$. for the age of the dolerite, which is also the best younger limit of the sediments of the Roraima Formation. The sediments may, of course, be appreciably older than $1,710 \mathrm{~m} . \mathrm{y}$. although work at present in progress on rocks which were

\begin{tabular}{|c|c|c|c|c|}
\hline \multicolumn{5}{|c|}{ Table 1} \\
\hline Sample & $\begin{array}{l}\text { Per } \\
\text { cent } \\
\mathbf{K}\end{array}$ & $\begin{array}{l}\text { Radio- } \\
\text { genic } \\
{ }^{10} \mathrm{Ar}\end{array}$ & $\begin{array}{l}\text { Atmospheric } \\
{ }^{40} \mathrm{Ar} \text { per cent } \\
\text { of total }{ }^{40} \mathrm{Ar}\end{array}$ & Age \\
\hline $\begin{array}{l}\text { OGS.63.9. Pyroxene-horn- } \\
\text { blende mixture from } \\
\text { middle zone of the Lower } \\
\text { Kopinang Dolerite Sill. } \\
\text { Three miles true north of } \\
\text { Velgraad airstrip. British } \\
\text { Guiana. }\end{array}$ & $0 \cdot 24$ & 0.046 p.p.m. & 1 per cent & $1,665 \pm 130 \mathrm{~m} . \mathrm{y}$ \\
\hline $\begin{array}{l}\text { OGS.63.7. Muscovite from } \\
\text { mica hornfels, specimen } \\
\text { No. K.311, immediately } \\
\text { above upper contact of the } \\
\text { Lower Kopinang Sill, } \\
\text { Kopinang River Valley. }\end{array}$ & $7 \cdot 97$ & 1.619 p.p.m. & nil & $1,735 \pm 70$ m.y. \\
\hline $\begin{array}{l}\text { OGS.63.8. Biotite from mica } \\
\text { hornfels. } K .311 \text {. } \\
\text { Decay constants } \lambda \beta \\
\text { Isotopie abundance }\end{array}$ & $6 \cdot 27$ & $\begin{array}{l}1.234 \text { p.p.m. } \\
2 \times 10^{-10} \mathrm{y}^{-1} \cdot \\
=0.0119 \text { aton }\end{array}$ & 1 per cent & $\begin{array}{l}1,700 \pm 65 \mathrm{~m} \cdot \mathrm{y} . \\
10^{-10} \mathrm{y}^{-1}\end{array}$ \\
\hline
\end{tabular}

